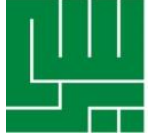

KATA KUNCI

KEYWORDS

ABSTRAK

\section{Hubungan Culture Intelligence dengan Organizational Citizenship Behavior melalui Kepemimpinan Transformasional}

\section{The Correlation between Culture Intelligence and Organizational Citizenship Behavior through Transformational Leadership}

\author{
Angela Irena Sindoro Dahzuki ${ }^{1}$, Aditya Nanda Priyatama ${ }^{2}$, Rafika Nur \\ Kusumawati $^{3}$ \\ ${ }^{1,2,3}$ Program Studi Psikologi Fakultas Kedokteran Universitas Negeri Sebelas Maret, Surakarta \\ Email : angela.irena11@gmail.com
}

culture intelligence, kepemimpinan transformasional, organizational citizenship behavior

culture intelligence, transformational leadership, organizational citizenship behavior

Perilaku yang tidak terdapat pada deksripsi pekerjaan secara formal dalam sebuah pekerjaan tetapi jika dilakukan akan dihargai atau dapat disebut sebagai Organizational Citizenship Behavior. Perilaku ini muncul karena terdapat sejumlah faktor yang mempengaruhi, salah satunya kepemimpinan transformasional. Selain karakteristik seorang pemimpin, organisasi perlu menyadari bahwa setiap karyawan mempunyai latar belakang budaya atau kultur yang berbeda. Culture Intelligence hadir untuk memahami keberagaman dari berbagai budaya. Penelitian ini bertujuan untuk (1) mengetahui hubungan culture intelligence dan organizational citizenship behavior dengan kepemimpinan transformasional sebagai variabel mediator, (2) mengetahui hubungan culture intelligence dan organizational citizenship behavior (3) mengetahui hubungan culture intelligence dengan kepemimpinan transformasional, (4) mengetahui hubungan kepemimpinan transformasional dan organizational citizenship behavior. Penelitian ini menggunakan purposive sampling dengan sampel sebanyak 73 karyawan yang terdiri dari 44 karyawan laki-laki dan 29 karyawan perempuan . Hasil uji hipotesis menunjukkan persamaan langsung antara culture intelligence dan organizational citizenship behavior sebesar 0,203, sementara persamaan tidak langsung antara culture intelligence dan organizational citizenship behavior yang dimediatori oleh kepemimpinan transformasional adalah sebesar 0,378. Penelitian ini bersifat mediasi sempurna dikarenakan hubungan culture intelligence dan organizational citizenship behavior bernilai tidak signifikan positif, sedangkan untuk hubungan culture intelligence dan kepemimpinan transformasional serta hubungan kepemimpinan transformasional dan 


\begin{abstract}
Behavior that is not formally prescribed in an employee's job description, but when it is voluntarily done, it is appreciated called as Organizational Citizenship Behavior. This behavior arises from a number of influencing factors, one of which is transformational leadership. In addition to the leader characteristics, an organization undoubtedly believes that each employee also possesses a plethora of different cultural backgrounds. Culture Intelligence exists as to understand the diversity of culture. This research aims to (1) understand the correlation between culture intelligence as well as organizational citizenship behavior and transformational leadership as the mediator variable, (2) understand the correlation between culture intelligence and organizational citizenship behavior, (3) understand the correlation between culture intelligence and transformational leadership, and (4) understand the correlation between transformational leadership and organizational citizenship behavior. This research used purposive sampling with 73 employees consists of 44 man and 29 woman as the samples. The hypothesis test results showed that the direct effect between culture intelligence and organizational citizenship behavior was as much as 0.203, and the indirect effect between culture intelligence and organizational citizenship behavior mediated by transformational leadership was as much as 0.378. This is a complete mediation research, for the correlation between culture intelligence and organizational citizenship behavior is insignificant positive, whereas the correlation between culture intelligence and transformational leadership as well as the correlation between transformational leadership and organizational citizenship behavior are positive and significant. Based on those aforementioned results, culture intelligence and organizational citizenship behavior mediated by transformational leadership have a significant and positive correlation.
\end{abstract}

\section{PENDAHULUAN}

Era globalisasi pada dewasa ini menuntut masyarakat agar bergerak cepat dalam menghadapi perubahan. Menurut UNDP (United Nations Development Programme) yang khusus menangani masalah pembangunan, menyatakan dalam Human Development Report 2016, indeks pembangunan manusia (IPM) di Indonesia berada pada peringkat 113 pada tahun 2015 . Hal ini menunjukkan terjadi penurunan kualitas sumber daya manusia dari tahun 2014 yang saat itu berada pada peringkat 110. (Fauzi, 2017) .
Persaingan globalisasi membuat perusahaan memerlukan karyawan yang mau bekerja melebihi dari tugas dan tanggung jawab pekerjaannya. Hal ini akan berdampak pada organisasi dan karyawan yang menemukan kendala dalam menyelesaikan tugas serta harapan dari tanggung jawab pekerjaannya (Othman, Arshad, Hashim, \& Isa, 2005). Jika karyawan tidak dapat menghasilkan kinerja yang baik bagi perusahaan, maka individu tersebut tidak akan bertahan lama dalam menghadapi perubahan yang akan terus terjadi. Perilaku extra role adalah perilaku yang tidak terdapat pada deksripsi pekerjaan secara formal dalam sebuah pekerjaan tetapi jika 
dilakukan akan dihargai karena meningkatkan efektivitas dan kelangsungan organisasi (Triningsih \& Wahyuni, 2003). Salah satu bentuk perilaku extra role yang akan dikaji dalam penelitian ini adalah Organizational Citizenship Behavior (OCB).

Wayne, Shore, dan Liden (1997) menyatakan bahwa OCB dapat dipengaruhi oleh hubungan karyawan dengan atasannya serta juga hubungannya dengan organisasi. Keinginan karyawan bukan hanya untuk melakukan hal yang tidak hanya sebatas kontrak ekonomi dalam perusahaan namun karyawan juga melakukan hal yang berlandaskan norma pertukaran sosial. Dengan demikian, peran pemimpin dalam keberjalanan sebuah organisasi tidak hanya melakukan hal manajerial perusahaan namun mampu berinteraksi sosial serta meningkatkan motivasi, moral dan kesadaran karyawannya.

Gaya kepemimpinan transformasional memiliki kemampuan untuk meningkatkan kinerja bawahan baik dalam perilaku in role maupun extra role. Kepemimpinan transformasional juga menyuarakan nilai-nilai moral dari para karyawannya untuk meningkatkan kesadaran mengenai masalah etika untuk membawa perubahan dalam organisasi (Burns dalam Yukl, 2010). Penelitian yang dilakukan oleh Kurniatami (2014) mengatakan bahwa kepemimpinan transformasional berkorelasi positif dengan OCB. Hal ini menandakan bahwa ketika seorang pemimpin yang memiliki serta menerapkan kepemimpinan transformasional di dalam organisasi, maka dapat memicu OCB pada karyawan semakin tinggi.

Selain dari karakteristik pemimpin, organisasi tentu menyadari bahwa setiap karyawan mempunyai latar belakang budaya atau kultur yang berbeda. Hal ini menjadi tugas bagi pemimpin sebuah organisasi global dalam menghadapi sebuah komposisi budaya dalam sebuah divisi kerja dan nilai-nilai dari karyawan yang secara dramatis berubah (Groves \& Feyerherm, 2011). Culture intelligence hadir di dalam organisasi sebagai kemampuan yang dimiliki individu dalam memahami secara meluas, memiliki keyakinan dengan kemampuan yang dimiliki, memiliki ketertarikan dalam menghadapi pengalaman baru serta mampu menyesuaikan perilaku baik secara verbal maupun non verbal dengan karakteristik multikultural untuk mencegah timbulnya hal-hal yang akan terjadi dalam situasi beragam latar budaya yang berbedabeda (Livermore, 2011).

Budaya merupakan salah satu faktor yang perlu diperhatikan saat mempelajari keefektifan seorang pemimpin dan konteks multikultural karyawan yang sangat beragam. Penelitian yang dilakukan oleh Box (2014) menyatakan bahwa kemampuan kepemimpinan transformasional yang diperkuat dengan culture intelligence penting bagi para pemimpin untuk memandu organisasi bergerak maju. Rendahnya tingkat culture intelligence dan kemampuan kepemimpinan transformasional dapat berdampak pada kurangnya efektifitas pemimpin yang mengakibatkan ketidaksetiaan bawahan, tidak menerapkan usaha yang lebih dan kurangnya kepuasan karyawan (dalam Jogulu, 2010; Thiederman, 2008). Hal ini menandakan bahwa culture intelligence dapat menjadi salah satu prediktor kepemimpinan transformasional. Penelitian yang dilakukan oleh Keung dan Rockinson-Szapkiw (2013) menyatakan bahwa culture inteliigence positif signifikan terhadap kepemimpinan transformasional. Hal ini menandakan pemimpin yang memiliki culture intelligence semakin tinggi menunjukkan tingkat gaya kepemimpinan transformasional yang lebih tinggi.

Organisasi yang berhasil menandakan bahwa karyawan mampu menghargai perbedaan kultural serta mendorong untuk mengenali perbedaan di antara tim secara positif (Narayanan \& Nirmala, 2016). Hal ini dikarenakan setiap tim di dalam organisasi baik dalam skala kecil maupun besar terdiri dari karakteristik setiap individu yang berbeda-beda termasuk dalam budaya tiap-tiap orang. OCB yang baik dapat mengarahkan karyawan untuk memiliki keterpaduan dalam kerjasama tim mengingat arus globalisasi yang tidak hanya membutuhkan sumber daya manusia yang memahami kemajuan teknologi dalam lingkungan bisnis akan tetapi juga memahami dan menghargai budaya yang berbeda dalam organisasi dan lingkungan bisnis. Semakin baik OCB yang dimiliki seorang karyawan serta memiliki culture intelligence yang baik dapat meningkatkan keefektifan dari sebuah organisasi.

Hadirnya pemimpin yang menjadi sebuah jembatan agar mendapatkan rasa kepercayaan, loyalitas, dan rasa hormat dari 
bawahannya dengan cara mengatur secara efektif karyawan yang memiliki berbeda-beda budaya dapat menjadi sebuah sarana untuk meningkatkan kelangsungan efektivitas dari sebuah organisasi. Penelitian yang dilakukan oleh Hur, Berg, dan Wilderom (2011) juga menyatakan bahwa kepemimpinan transformasional dapat memediasi hubungan antara emotional intelligence dan kinerja tim. Hal ini menandakan kepemimpinan transformasional dapat menjadi variabel mediator yang baik untuk menghubungkan satu variabel dengan variabel lainnya.

Robbins dan Judges

mendefinisikan organizational citzienship behavior sebagai perilaku perseorangan yang sukarela dan bukan termasuk dalam bagian persyaratan formal sebuah pekerjaan, tetapi dapat meningkatkan fungsi efektif dari organisasi. OCB (Organ, Podsakoff, \& MacKenzie, 2006) merupakan perilaku individu yang bebas dan meningkatkan fungsi efektif organisasi. Perilaku bebas tersebut bukan bagian dari deskripsi pekerjaan karyawan (job description) dan keputusan yang dilakukan oleh pribadi karyawan itu sendiri, sehingga karyawan tersebut tidak akan mendapat punishment dari perusahaan ketika tidak melakukan perilaku OCB di dalam tempat kerja. Aspek-aspek OCB menurut Organ, Podsakoff, dan MacKenzie (2006) yaitu altruism, conscientiousness, sportmanship, courtesy, dan civic virtue. Sebab munculnya OCB tidak hanya instrinsik karyawan, namun dapat berasal dari eksternal dari karyawan tersebut yatu pada perilaku pemimpin dan konteks kultural dalam sebuah organisasi.

Lingkungan yang multikultural membuat individu harus beradaptasi dengan budaya yang berbeda-beda. Budaya merupakan sekumpulan nilai, keyakinan, sikap dan perilaku yang dimiliki bersama oleh sebuah kelompok yang kemudian dikomunikasikan dari generasi satu ke generasi lainnya berupa bahasa atau jenis komunikasi (Matsumoto, 2008). Culture intelligence merupakan sebuah kapabilitas yang efektif dalam berbagai konteks kultural seperti etnik, generasi dan budaya organisasi Livermore (2011). Ang, Van Dyne, dan Koh (2006) mendefinisikan culture intelligence sebagai kemampuan seseorang untuk mengatur serta mengelola secara efektif pada budaya yang berbeda. Tidak hanya sebagai kemampuan seseorang untuk memahami perbedaan dan berinteraksi dengan tata krama budaya yang sensitif, culture intelligence juga menjadi faktor yang berkontribusi efektif dalam kepemimpinan di segala bisnis yang multi-budaya. Stenberg (dalam Ang dan Van Dyne, 2008) menyatakan bahwa culture intelligence memiliki empat dimensi yang saling berkaitan, yaitu, kecerdasan metakognisi ( $C Q$ drive), kecerdasan kognisi (CQ Knowledge), kecerdasan motivasi ( $C Q$ Strategy), dan kecerdasan perilaku ( $C Q$ Action).

Sebagai respon untuk meningkatkan globalisasi dalam pekerjaan, manajer dalam setiap level harus mampu mencapai kemampuan baru, yaitu kemampuan dalam memahami perbedaan budaya dan kesadaran intelektual di dalam tempat kerja (Thiederman, 2008). Kompetensi kepemimpinan dalam abad ke-21 ini belum memiliki komponen budaya dimana terjadi disposisi atau aksi yang termasuk memahami budaya setempat dan perilaku dalam aktivitas perekonomian (Box, 2014). Hughes, Ginnett, dan Curphy (2012) menyatakan bahwa pemimpin transformasional memiliki visi, keahlian dalam komunikasi, serta mengelola kesan yang baik dan untuk mengembangkan ikatan emosional yang kuat antara pemimpin dengan bawahannya. Hal ini akan memicu motivasi serta perasaan dari bawahannya untuk sedia dalam mewujudkan visi dan misi dari organisasi.

Hasil yang akan didapatkan ketika kepemimpinan transformasional berhasil dilakukan adalah tingkah laku dari para bawahannya yang bersedia secara sukarela demi organisasi, kepuasan para anggota, peningkatan kinerja karyawan, kelompok, dan organisasi, serta komitmen personal dari bawahan kepada pemimpinnya dan visi organisasi tersebut. (Kreitner dan Kinicki, 2014). Yukl (2010) mendefinisikan kepemimpinan transformasional sebagai kepemimpinan yang mempengaruhi bawahannya sehingga mendapatkan rasa kepercayaan, kebanggaan, loyalitas dan rasa hormat terhadap atasan dan memotivasi bawahan untuk melakukan sesuatu yang lebih dari apa yang diharapkan. Kata kepemimpinan transformasional berasal dari kata kerja yaitu to transform yang artinya kemampuan seorang pemimpin untuk mengarahkan bawahan serta organisasinya menuju perubahan yang lebih baik. 
Efektivitas seorang pemimpin diperlukan supaya perilaku Organizational Citizenship Behavior dapat ditunjukkan dengan baik oleh bawahannya (Rahmi, 2013). Robbins dan Judge (dalam Prabowo, 2014) juga menyatakan kepemimpinan transformasional dapat mempengaruhi bawahan dengan menciptakan perasaan percaya pada pengikutnya. Seorang pemimpin transformasional dapat membuat bawahannya bekerja lebih dari apa yang diharapkan dan mau untuk bekerja lebih dari deskripsi pekerjaannya. Yukl (2010) menyatakan aspekaspek di dalam kepemimpinan transformasional terdiri atas pengaruh yang ideal (idealized influence), motivasi yang inspirasional (inspirational motivation), stimulasi intelektual (intellectual stimulation), serta pertimbangan yang bersifat individual (individualized consideration). Beberapa situasi di dalam organisasi dapat memperbesar kemungkinan kepemimpinan transformasional dapat menguatkan pengaruhnya pada pengikut atau tidak yaitu dengan lingkungan yang tidak stabil, budaya dari pengusaha, struktur organik (bukan birokrasi mekanistis) dan dominansi dari unit perluasan-batas atas inti teknis.

Dalam penelitian ini diajukan beberapa rumusan masalah yaitu: (a) apakah terdapat hubungan culture intelligence dengan organizational citizenship behavior melalui kepemimpinan transformasional, (b) apakah terdapat hubungan antara culture intelligence dengan kepemimpinan transformasional, (c) apakah terdapat hubungan antara kepemimpinan transformasional dengan organizational citizenship behavior, (d) apakah terdapat hubungan antara culture intelligence dengan organizational citizenship behavior. Dari rumusan masalah tersebut, maka dikemukakan pula hipotesis yaitu; (a) terdapat hubungan culture intelligence dengan organizational citizenship behavior melalui kepemimpinan transformasional, (b) terdapat hubungan antara culture intelligence dengan organizational citizenship behavior, (c) terdapat hubungan antara culture intelligence dengan kepemimpinan transformasional, (d) terdapat hubungan antara kepemimpinan transformasional dengan organizational citizenship behavior.

\section{METODE PENELITIAN}

Penelitian ini merupakan penelitian kuantitatif dimana melibatkan karyawan di sebuah organisasi sebagai responden penelitian. Pengambilan data dilakukan pada saat jam istirahat kantor yaitu pukul 12.00-13.00. Sebelum dilakukan uji hipotesis, telah dilakukan uji asumsi dasar yaitu uji normalitas dan uji linearitas serta uji asumsi klasik yaitu uji heteroskedastisitas dan uji autokorelasi. Populasi dalam penelitian ini adalah karyawan di sebuah divisi produksi dalam organisasi dengan jumlah sebanyak 150 orang karyawan. Teknik pengambilan sampel dalam penelitian ini menggunakan purposive sampling. Penentuan sampel dalam penelitian ini berdasarkan ciri atau karakteristik tertentu yaitu status sebagai karyawan tetap, memiliki masa kerja maksimal kurang lebih dari setahun, dan berada di posisi staff. Berdasarkan karakteristik penelitian tersebut, terdapat 73 karyawan divisi produksi yang terdiri dari beberapa bagian.

Pengumpulan data dalam penelitian ini dengan menyebarkan kuisioner dan keseluruhan kuisioner tersebut digunakan dalam analisis data. Pengambilan data menggunakan skala culture intelligence, skala kepemimpinan transformasional, dan skala OCB yang telah memenuhi validitas dan reliabilitasnya. Skala culture intelligence yang digunakan dalam penelitian ini berdasarkan aspek-aspek yang diadaptasi dari skala yang dibuat oleh Ang, Van Dyne, dan Koh (2006) yang dimodifikasi oleh peneliti. Kepemimpinan transformasional dalam penelitian ini akan diukur melalui adaptasi skala kepemimpinan transformasional oleh Zhu, Avolio, Walumba (2009). Organizational citizenship behavior karyawan akan diukur menggunakan skala yang diadaptasi oleh penelitian Fox, Spector, Goh, Bruursema, dan Kessler (2009).

Validitas skala dalam penelitian ini menggunakan corrected item total correlation dengan menggugurkan aitem skala yang memiliki koefisien korelasi di bawah 0,3 . Uji reliabilitas menggunakan formula Alpha Cronbach. Berdasarkan hasil uji validitas dan reliabilitas pada culture intelligence terdapat 14 aitem valid dengan koefisien reliabilitas sebesar 0,843, kemudian pada skala kepemimpinan transformasional terdapat 19 aitem valid dengan koefisien reliabilitas 0,895, dan pada skala organizational citizenship behavior terdapat 22 aitem valid dengan 
koefisien reliabilitas sebesar 0,910. Data penelitian diolah dengan menggunakan statistik dengan bantuan program SPSS versi 22.0. Teknik analisis data menggunakan uji parametrik yaitu uji regresi berganda dan analisis jalur untuk mengetahui besarnya pengaruh variabel mediator dalam penelitian ini.

\section{ANALISIS \& HASIL}

Berdasarkan hasil analisis data menggunakan uji hipotesis regresi linier berganda dan uji korelasi parsial, diketahui bahwa: (a) terdapat hubungan yang signifikan antara culture intelligence dan kepemimpinan transformasional dengan organizational citizenship behavior, (b) tidak terdapat hubungan signifikan antara culture intelligence dan organizational citizenship behavior, (c) terdapat hubungan yang signifikan antara kepemimpinan transformasional dengan organizational citizenship behavior. Berikut merupakan uji hipotesis uji regresi dalam penelitian ini:

Tabel 1. Hasil Uji Regresi

\begin{tabular}{|c|c|c|c|c|c|}
\hline Model & $\begin{array}{l}\text { Sum of } \\
\text { Squares }\end{array}$ & df & $\begin{array}{l}\text { Mean } \\
\text { Square }\end{array}$ & $\mathrm{F}$ & Sig. \\
\hline 1 Regression & 880.966 & 2 & 440.483 & 8.909 & $.000^{\mathrm{a}}$ \\
\hline Residual & 3461.006 & 70 & 49.443 & & \\
\hline Total & 4341.973 & 72 & & & \\
\hline
\end{tabular}

Berikut merupakan uji hipotesis yaitu uji korelasi parsial dalam penelitian ini:

Tabel 2. Hasil Uji Korelasi Parsial

\begin{tabular}{|c|c|c|c|c|}
\hline \multirow[t]{2}{*}{ Model } & \multirow[t]{2}{*}{ Sig. } & \multicolumn{3}{|c|}{ Correlations } \\
\hline & & $\begin{array}{c}\text { Zer } \\
\text { o- } \\
\text { orde } \\
\text { r } \\
\end{array}$ & Partial & Part \\
\hline 1 (Constant) & .001 & & & \\
\hline$C Q$ & .126 & .378 & .182 & .165 \\
\hline $\begin{array}{l}\text { KTRANSF } \\
\text { ORMASIO } \\
\text { NAL }\end{array}$ & .025 & .419 & .264 & .245 \\
\hline
\end{tabular}

Pengujian hipotesis pertama atau untuk mengetahui hubungan signifikan melalui variabel mediator menggunakan teknik analisis jalur. Analisis jalur merupakan perluasan dari analisis regresi linier dengan tujuan untuk menganalisa adanya variabel intervening (mediasi) yang menghubungkan antara variabel bebas dengan variabel terikat. Hasil yang didapatkan melalui perhitungan analisis jalur adalah, persamaan langsung antara culture intelligence dengan organizational citizenship behavior didapatkan hasil sebesar 0,203, sedangkan untuk persamaan tidak langsung antara culture intelligence dengan organizational citizenship behavior melalui variabel mediator yaitu kepemimpinan transformasional sebesar 0,378. Berikut merupakan bagan perhitungan analisis jalur:

Gambar 1. Analisis Jalur

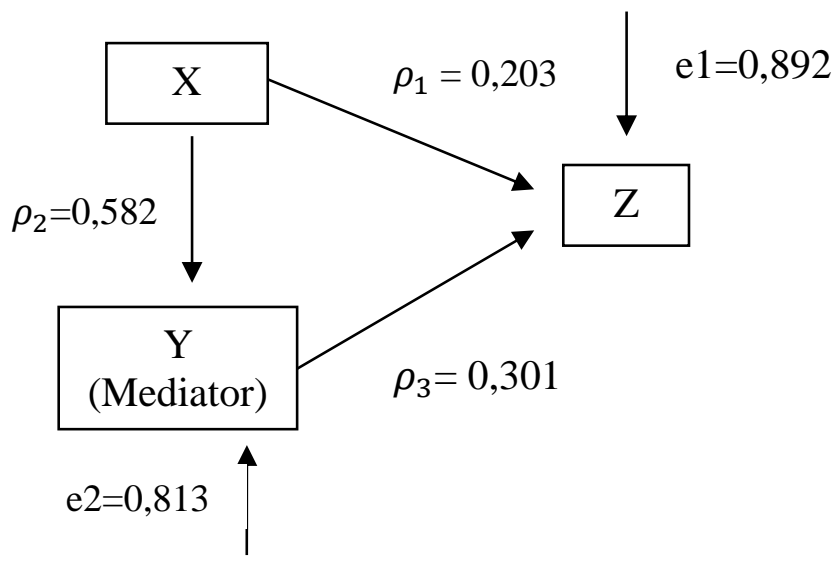

Nilai $\rho_{2}$ merupakan nilai standard coefficients beta dari hasil perhitungan uji regresi linier antara culture intelligence dan kepemimpinan transformasional. Diketahui bahwa terdapat hubungan yang signifikan antara culture intelligence dan kepemimpinan transformasional dengan nilai signifikansi $0,000(\mathrm{p}<0,05)$.

Tabel 3. Hasil Model Summary

\begin{tabular}{lrrrr}
\hline Model & $\mathrm{R}$ & $\begin{array}{c}\mathrm{R} \\
\text { Square }\end{array}$ & $\begin{array}{r}\text { Adjusted } \\
\text { R Square }\end{array}$ & $\begin{array}{c}\text { Std. Error } \\
\text { of the } \\
\text { Estimate }\end{array}$ \\
\hline 1 &, $450^{\mathrm{a}}$ &, 203 &, 180 & 7,032 \\
\hline
\end{tabular}

a. Predictors: (Constant), KTRANSFORM, CQ

b. Dependent Variable: OCB

Tabel 3 merupakan hasil analisis regresi yang memperlihatkan seberapa kuat pengaruh variabel bebas terhadap variabel terikat dan nilai koefisien determinasi $\left(\mathrm{R}^{2}\right)$ antara variabel culture intelligence dan kepemimpinan transformasional. Dari hasil tersebut dapat disimpulkan variabel culture intelligence dan 
kepemimpinan transformasional menyumbang pengaruh sebesar $20,3 \%$ sedangkan sisanya sebesar 79,7\% merupakan sumbangan dari faktor-faktor diluar variabel penelitian. Persentase sumbangan pengaruh diatas didapat dari total sumbangan efektif variabel culture intelligence sebesar $5,12 \%$ dan kepemimpinan transformasional sebesar $15,16 \%$. Selain itu, variabel culture intelligence dan kepemimpinan transformasional memberikan sumbangan relatif masing-masing sebesar $25,27 \%$ dan $74,72 \%$.

\section{DISKUSI}

Hasil pengajuan hipotesis dalam penelitian ini membuktikan bahwa, hipotesis pertama yaitu terdapat hubungan antara culture intelligence dengan organizational citizenship behavior dengan kepemimpinan transformasional dapat diterima. Berdasarkan hasil dari perhitungan analisis jalur, hal ini menandakan pengaruh tidak langsung antara culture intelligence dengan organizational citizenship behavior melalui variabel mediator yaitu kepemimpinan transformasional memiliki pengaruh yang lebih besar dibandingkan pengaruh secara langsung.

Lingkungan bisnis yang multi-kultural membutuhkan kepemimpinan yang efektif, dimana pemimpin memiliki kesadaran yang tinggi dalam menghadapi globalisasi dan dampak isu multikultural (McComas, 2015). Pentingnya keberadaan pemimpin menjadi role model bagi karyawannya secara tidak langsung akan memengaruhi karyawan dalam kinerja pekerjaan maupun dalam sikap atau tutur kata. Penelitian yang dilakukan oleh Hur, Berg, dan Wilderom (2011) mengatakan bahwa kepemimpinan transformasional dapat memediasi hubungan antara emotional intelligence dan kinerja tim. Hadirnya pemimpin yang menjadi sebuah jembatan agar mendapatkan rasa kepercayaan, loyalitas, dan rasa hormat dari bawahannya dengan cara mengatur secara efektif karyawan yang memiliki berbeda-beda budaya dapat menjadi sebuah sarana untuk meningkatkan kelangsungan efektivitas dari sebuah organisasi. Semakin tinggi culture intelligence yang dimiliki seorang pemimpin, maka pemimpin transformasional mampu meningkatkan organizational citizenship behavior karyawan. Kompetensi culture intelligence dalam pemimpin dapat menjadi keterampilan sebagai pedoman bagi pemimpin dalam memanajemen sistem organisasi dan timnya (Box, 2014).

Hipotesis pertama juga didukung oleh pernyataan hipotesis kedua yaitu berdasarkan hasil uji korelasi parsial culture intelligence dan organizaional citizenship behavior dimana dapat disimpulkan bahwa variabel culture intelligence tidak memiliki hubungan yang signifikan dengan organizational citizenship behavior. Hasil tersebut berbeda dengan penelitian yang dilakukan oleh Narayanan \& Nirmala (2016) yang menyatakan bahwa terdapat hubungan yang positif antara culture intelligence dan organizational citizenship behavior.

Pendapat yang sedikit berbeda dijelaskan oleh Baron dan Kenny (dalam Widhiarso, 2010) yang menyatakan model mediator yang sempurna dapat terjadi ketika variabel bebas tidak signifikan dengan variabel terikat. Hal ini dikarenakan agar variabel mediator dalam sebuah penelitian dapat diuji kesempurnaan model mediatornya. Hipotesis mediasi menempatkan bagaimana sebuah variabel bebas akan mempengaruhi variabel terikat melalui satu atau lebih variabel mediator (Widhiarso, 2010). Strategi casual step yang digunakan untuk uji mediasi melalui analisis jalur menyatakan bahwa apabila koefisien $\rho_{2}$ dan $\rho_{3}$ signifikan, hal tersebut sudah membuktikan adanya mediasi meskipun $\rho_{1}$ tidak signifikan. Hal ini lah yang disebut dengan mediasi sempurna. Oleh karena itu, penelitian ini dapat disimpulkan sebagai mediasi sempurna dimana variabel bebas tidak signifikan dengan variabel terikat.

Selain itu, penelitian yang dilakukan oleh Lai, Lam dan Lam (dalam Podsakoff, MacKenzie, \& Podsakoff, 2015) menyatakan bahwa budaya tim dapat mempengaruhi jenis organizational citizenship behavior yang lebih berpengaruh pada kinerja tim. Halbesleben dan Bellairs (dalam Podsakoff, Mackenzie, \& Podsakoff, 2015) juga menyatakan bahwa terdapat perbedaan motif setiap individu seperti motif prososial, kepentingan organisasi, peningkatan manajemen dapat mempengaruhi pengaruh setiap individu untuk terikat berbagai variasi dari OCB dan hal tersebut bergantung pada situasi dan konteksnya. 
Berdasarkan hasil uji regresi sederhana yang dilakukan, terdapat hubungan yang positif dan signifikan antara culture intelligence dan kepemimpinan transformasional sehingga hipotesis ketiga dalam penelitian ini diterima. Hasil penelitian ini juga didukung oleh penelitian yang dilakukan oleh Keung \& Rockinson-Szapkiw (2013) juga menunjukan bahwa adanya hubungan signifikan anntara culture intelligence dengan kepemimpinan transformasional. Aspek perilaku dan kognitif dalam culture intelligence juga ditemukan menjadi prediktor terbaik dalam kepemimpinan transformasional. Hal ini menandakan bahwa pemimpin yang memiliki culture intelligence yang tinggi menunjukkan gaya kepemimpinan transformasional yang tinggi pula sehingga, dapat dikatakan individu yang memiliki culture intelligence yang tinggi mampu untuk memimpin dan mengatur secara efektif orangorang di lingkungan budaya yang berbedabeda.

Selain itu, korelasi parsial variabel kepemimpinan transformasional dan organizational citizenship behavior dapat disimpulkan bahwa variabel kepemimpinan transformasional memiliki hubungan yang signifikan dengan organizational citizenship behavior. Hal ini sejalan dengan hasil penelitian Kurniatami (2014) serta penelitian yang dilakukan oleh Khan, Gouri dan Awang (2013) yang menunjukkan bahwa terdapat hubungan positif dan signifikan antara kepemimpinan transformasional dengan organizational citizenship behavior. Hal ini dikarenakan, pemimpin transformasional mampu membuat karyawan memiliki rasa percaya dengan pemimpinnya sehingga memicu adanya OCB pada karyawan (Prabowo, 2014). Seorang pemimpin transformasional dapat membuat bawahannya bekerja lebih dari apa yang diharapkan dan mau untuk bekerja lebih dari deskripsi pekerjaannya.

\section{SIMPULAN}

Berdasarkan hasil penelitian yang diperoleh, maka dapat diambil beberapa kesimpulan, yaitu terdapat hubungan yang signifikan antara culture intelligence dengan organizational citizenship behavior melalui kepemimpinan transformasional, tidak terdapat hubungan yang signifikan antara culture intelligence dengan organizational citizenship behavior, terdapat hubungan yang signifikan antara kepemimpinan transformasional dengan organizational citizenship behavior dan terdapat hubungan yang signifikan antara culture intelligence dengan kepemimpinan transformasional.

Selain itu sumbangan efektif culture intelligence sebesar $5,12 \%$ kepemimpinan transformasional sebesar $15,16 \%$ sehingga total sumbangan efektif yang diberikan variabel culture intelligence dan kepemimpinan transformasional terhadap organizational citizenship behavior sebesar 20,3\%. Sedangkan, sumbangan relatif variabel culture intelligence terhadap organizational citizenship behavior sebesar $25,27 \%$, sedangkan variabel kepemimpinan transformasional memberikan sumbangan relatif terhadap organizational citizenship behavior sebesar 74,72\%. Secara umum variabel kepemimpinan transformasional memberikan sumbangan efektif bagi organizational citizenship behavior karyawan lebih besar dibandingkan dengan variabel culture intelligence.

\section{SARAN}

Berdasarkan hasil penelitian yang dilakukan, maka peneliti memberikan beberapa saran atau masukan baik bagi perusahaan, bagi karyawan, dan bagi peneliti selanjutnya. Dengan adanya penelitian ini, peneliti berharap dapat menjadi masukan bagi para peneliti selanjutnya yang ingin melakukan penelitian dibidang yang sama khususnya menggunakan tema atau variabel yang sama. Selain itu, peneliti juga berharap penelitian ini dapat berguna sebagai bahan referensi dan sumber rujukan pustaka bagi penelitian dengan variabel serupa. Penelitian selanjutnya juga sebaiknya dapat menyempurnakan penelitian sebelumnya dengan memperluas populasi dan mengeksplorasi lebih lanjut mengenai variabel dalam penelitian ini beserta faktor lain yang mempengaruhi sehingga hasil penelitian diharapkan dapat komprehensif.

\section{DAFTAR PUSTAKA}

Ang, S., Van Dyne, L., \& Koh, C. (2006). Personality correlates of the fourfactor model of cultural intelligence. Groups \& Organizational Management, 31(1), 100-124. 
Ang, S., \& Van Dyne, L. (2008). Handbook of cultural intelligence: Theory, measurement, and applications. Armonk, NY: M. E. Sharpe.

Box, J. B. (2014). The Relationship between Cultural Intelligence and Transformational Leadership. Northcentral University, Bisnis dan Teknologi Manajemen. Arizona: Northcentral University.

Fauzi, Y. (2017). Ranking Indeks Pembangunan Manusia Indonesia Turun ke-113. Diakses Desember 1, 2017, dari CNN Indonesia: https://www.cnnindonesia.com/ekono $\mathrm{mi} / 20170322182446-78$ -

202081/ranking-indeks-pembangunanmanusia-indonesia-turun-ke-113/.

Fox, S., Spector, P. E., Goh, A., Bruursema, K., \& Kessler, S. R. (2009). The deviant citizen: Clarifying the measurement of organizational citizenship behavior and its relation to counterproductive work behavior. Loyola: University Chicago.

Groves, K. S., \& Feyerherm, A. E. (2011). Leader Cultural Intelligence in Context: Testing the Moderating Effects of Team Cultural Diversity on Leader and Team Performance. Group \& Organization Management, $X X(10), 1-32$.

Hughes, R.L., Ginnett, R.C., dan Curphy, G.J. (2012). Leadership: Memperkaya Pelajaran dari Pengalaman. Edisi Ketujuh. Jakarta: Salemba Humanika.

Hur, Y., Berg, P. T., \& Wilderom, C. P. (2011). Transformational Leadership as a Mediator between Emotional Intelligence and Team Outcomes. The Leadership Quartely, XXII(4), 591-603.

Jogulu, Uma D. (2010). Culturally-linked leadership styles. Leadership \& Organization Development Journal, 31(8), 705-719.

Keung, E. K., \& Rockinson-Szapkiw, A. J. (2013). The Relationship between Transformational Leadership and Culture Intelligence: A Study of International School Leadership.
Journal of Educational Administration, 51(6), 836-854.

Khan, Naveed R., Awang, Marinah \& Ghouri, Arsalan Mujahid. (2013). Leadership Styles and Organizational Behavior in Small and Medium Scale Firms. Journal of Arts, Science \& Commerece. 4 (2), 144-154.

Kreitner, Robert dan Kinicki, Angelo. (2014). Organizational behavioral-Ed. 5 . Boston: McGraw-Hill.

Kurniatami, Y. (2014). UMS ETD- $d b$. Diakses April 16, 2017, dari Hubungan Antara Kepemimpinan Transformasional dengan Organization Citizenship Behavior (OCB) di Universitas Muhammadiyah Surakarta (UMS).

Livermore, D. (2011). The Cultrual Intelligence Differences: master the one skill you can't do without in today's global economy. New York: AMACOM.

McComas, A. b. (2015). The Relationship of a Leader's Cultural Intelligence to Organizational Citizenship Behaviors in a Multicultural Work Group. Ann Arbor: ProQuest LLC.

Matsumoto, D. (2008). Pengantar Psikologi Lintas Budaya. Yogyakarta: Pustaka Pelajar.

Narayanan, B. L., \& Nirmala, D. (2016). A Study of Cultural Intelligence of Employees and Its Relationship with Organizational Citizenship Behavior in a Multinational Company. Journal of Humanities and Social Science, 53-59.

Organ, D. W., Podsakoff, P. M., \& MacKenzie, S. B. (2006). Organizational Citizenship Behavior: Its Nature, antecedents, and Consequences. London: Sage Publication Inc.

Othman, R., Arshad, R., Hashim, N., \& Isa, R. (2005). Psychological Contract Violation and Organizational Citizenship Behavior. Gadjah Mada International Journal of Business , 7 (3), 325-349. 
Prabowo, A. (2014). Analisis Pengaruh Kepemimpinan Transformasional dan Kepuasan Kerja Terhadap Organizational Citizenship Behavior $(O C B)$ dengan Komitmen Organisasi sebagai Variabel Intervening. Universitas Diponegoro, Fakultas Ekonomika dan Bisnis. Semarang: eprints undip.

Podsakoff, P. M., MacKenzie, S. B., \& Podsakoff, N. P. (2015). A Cultural Prespective on Organizational Citizenship Behavior. Dalam P. C. Earley, \& G. Galic, The Oxford Handbook of Organizational Citizenship Behavior. Oxford: Oxford University Press.

Rahmi, Maptuhah. (2013). Pengaruh Kepemimpinan Transformasional terhadap Organizational Citizenship Behavior: Studi pada Guru Tetap SMA Negeri di Kabupaten Lombok Timur. Bali: Universitas Udayana.

Robbins, S., \& Judge, T. A. (2015). Perilaku Organisasi. Jakarta: Salemba Empat.

Thiederman, S. (2008). Making diversity work: Seven steps for defeating bias in the workplace. New York: Kaplan.

Triningsih, E., \& Wahyuni, S. (2003). Pengaruh Atribut Kepribadian terhadap Organizational Citizenship Behavior (Studi pada Karyawan PT. Pondok Solo Permai, Solo Baru, Sukoharjo). Jurnal Fokus Manajerial, 1 (2), 89-101.

Wayne, S. J., Shore, L. M., \& Liden, R. C. (1997). Perceived Organizational Support and Leader-Member Exchange: A Social Exchange Prespective. Academy of Management Journal, 40(1), 82-111.

Widhiarso, W. (2010). Berkenalan dengan Analisis Mediasi: Regresi dengan Melibatkan Variabel Mediator (Bagian Pertama). Diakses Mei 19, 2018.

Yukl, G. (2010). Kepemimpinan dalam Organisasi. (E. Tanya, Penyunt., \& B.
Supriyatno, Penerj.) Jakarta: PT Indeks.

Zhu, W., Avolio, B. J., Walumbwa, F. O. (2009). Moderating role of follower characteristics with transformational leadership and follower work engagement. Group and Organization Management, 34, 590-619. 